University of Nebraska - Lincoln

DigitalCommons@University of Nebraska - Lincoln

2006

\title{
Evaluation of Average Daily Gain Prediction by Level One of the 1996 National Research Council Beef Model and Development of Net Energy Adjusters
}

\author{
H. C. Block \\ University of Nebraska-Lincoln \\ Terry Klopfenstein \\ University of Nebraska-Lincoln, tklopfenstein1@unl.edu \\ Galen E. Erickson \\ University of Nebraska-Lincoln, gerickson4@unl.edu
}

Follow this and additional works at: https://digitalcommons.unl.edu/animalscifacpub

Part of the Animal Sciences Commons

Block, H. C.; Klopfenstein, Terry; and Erickson, Galen E., "Evaluation of Average Daily Gain Prediction by Level One of the 1996 National Research Council Beef Model and Development of Net Energy Adjusters" (2006). Faculty Papers and Publications in Animal Science. 466.

https://digitalcommons.unl.edu/animalscifacpub/466

This Article is brought to you for free and open access by the Animal Science Department at DigitalCommons@University of Nebraska - Lincoln. It has been accepted for inclusion in Faculty Papers and Publications in Animal Science by an authorized administrator of DigitalCommons@University of Nebraska - Lincoln. 


\title{
Evaluation of average daily gain prediction by level one of the 1996 National Research Council beef model and development of net energy adjusters ${ }^{1}$
}

\author{
H. C. Block, ${ }^{2}$ T. J. Klopfenstein, ${ }^{3}$ and G. E. Erickson \\ Department of Animal Science, University of Nebraska, Lincoln 68583-0908
}

\begin{abstract}
Two data sets were developed to evaluate and refine feed energy predictions with the beef National Research Council (NRC, 1996) model level 1. The first data set included pen means of group-fed cattle from 31 growing trials (201 observations) and 17 finishing trials (154 observations) representing over 7,700 animals fed outside in dirt lots. The second data set consisted of 15 studies with individually fed cattle (916 observations) fed in a barn. In each data set, actual ADG was compared with ADG predicted with the NRC model level 1, assuming thermoneutral environmental conditions. Next, the observed ADG (kg), TDN intake $(\mathrm{kg} / \mathrm{d})$, and TDN concentration ( $\mathrm{kg} / \mathrm{kg}$ of DM) were used to develop equations to adjust the level 1 predicted diet $\mathrm{NE}_{\mathrm{m}}$ and $\mathrm{NE}_{\mathrm{g}}$ (diet $\mathrm{NE}$ adjusters) to be applied to more accurately predict $\mathrm{ADG}$. In both data sets, the NRC (1996) model level 1 inaccurately predicted ADG $(P<$ 0.001 for slope $=1$; intercept $=0$ when observed $\mathrm{ADG}$ was regressed on predicted ADG). The following nonlin-
\end{abstract}

ear relationships to adjust $\mathrm{NE}$ based on observed ADG, TDN intake, and TDN concentration were all significant $(P<0.001)$ : NE adjuster $=0.7011 \times 10^{(-0.8562 \times \mathrm{ADG})}$ $+0.8042, \mathrm{R}^{2}=0.325, \mathrm{~s}_{\mathrm{y} \cdot \mathrm{x}}=0.136 \mathrm{~kg} ; \mathrm{NE}$ adjuster $=$ $4.795 \times 10^{(-0.3689 \times \text { TDN intake })}+0.8233, \mathrm{R}^{2}=0.714, \mathrm{~s}_{\mathrm{y} . \mathrm{x}}=$ $0.157 \mathrm{~kg}$; and NE adjuster $=357 \times 10^{(-5.449 \times \mathrm{TDN} \text { concentra- }}$ tion) $+0.8138, \mathrm{R}^{2}=0.754, \mathrm{~s}_{\mathrm{y} \cdot \mathrm{x}}=0.127 \mathrm{~kg}$. An NE adjuster $<1$ indicates overprediction of ADG. The average NE adjustment required for the pen-fed finishing trials was 0.820 , whereas the $(P<0.001)$ adjustment of 0.906 for individually fed cattle indicates that the pen-fed environment increased $\mathrm{NE}$ requirements. The use of these equations should improve $\mathrm{ADG}$ prediction by the NRC (1996) model level 1, although the equations reflect limitations of the data from which they were developed and are appropriate only over the range of the developmental data set. There is a need for independent evaluation of the ability of the equations to improve ADG prediction by the NRC (1996) model level 1.

Key words: beef cattle, model evaluation, net energy

(C2006 American Society of Animal Science. All rights reserved.

J. Anim. Sci. 2006. 84:866-876

\section{INTRODUCTION}

The National Research Council (NRC) beef cattle model (NRC, 1996, 2000) level 1 has inaccurately predicted the gain of beef cattle, especially at low rates of gain (Patterson et al., 2000; Block et al., 2001; Fox et al., 2004). Block et al. (2001) recommended refinement to improve the prediction of animal performance. Problems with converting TDN to DE related to nutrient composition of feed (NRC, 2001), DE to ME related to intake, age of animal, and feed source (Agricultural

\footnotetext{
${ }^{1}$ A contribution of the University of Nebraska Agricultural Research Division, Lincoln, NE 68583. Journal Series No. 14605. This research was supported in part by funds provided through the Hatch Act.

${ }^{2}$ Current address: 204-624 8th Street East, Saskatoon, SK, Canada, S7H 0R2.

${ }^{3}$ Corresponding author: tklopfenstein1@unl.edu

Received October 19, 2004.

Accepted November 18, 2005.
}

Research Council, 1980; Commonwealth Scientific and Industrial Research Organization, 1990; both cited in NRC, 2001), and ME to NE (Garrett, 1980) may be responsible for the inaccuracy of gain predictions. Data used to develop equations for conversion of $\mathrm{ME}$ to $\mathrm{NE}$ were unequally distributed (Garrett, 1980) and scarce outside the range of 2.0 to $3.0 \mathrm{Mcal}$ of $\mathrm{ME} / \mathrm{kg}$. Additionally, short-term effects of previous nutrition, gut fill, or anabolic implants, and variation in $\mathrm{NE}_{\mathrm{m}}$ requirements (NRC, 1996), and the presumed effect of cold weather on the estimation $\mathrm{NE}_{\mathrm{m}}$ requirement (Block, 1999), may contribute to inaccurate $\mathrm{ADG}$ prediction.

Level 1 of the NRC beef cattle model contains a mechanism to make specific adjustments that allow alteration of the $\mathrm{NE}$ value of the diet, permitting accurate prediction of gain (NRC, 2000). The objectives of this study were to use historical data for further evaluation of the prediction of gain by the NRC beef cattle model level 1 , and to develop equations to predict the level of $\mathrm{NE}_{\mathrm{m}}$ and $\mathrm{NE}_{\mathrm{g}}$ adjustment required to improve the accuracy of gain predictions. 
Table 1. Description of growing trials used in evaluation of the NRC (1996) model level 1 and development of NE adjustment equations

\begin{tabular}{|c|c|c|c|c|c|c|c|}
\hline Trial & $\mathrm{SBW}^{1}$ & DMI, kg & $\mathrm{ADG}, \mathrm{kg}$ & TDN, $\%$ & $\mathrm{n}^{2}$ & $\mathrm{n}^{3}$ & Ingredients $^{4}$ \\
\hline Paterson et al. (1980a) & 262.0 & 6.03 & 0.39 & 51.30 & 326 & 9 & Alfalfa hay, corn cobs, corn stalks \\
\hline Paterson et al. (1980b) & 249.3 & 6.78 & 0.53 & 55.53 & 120 & 4 & Alfalfa hay, corn cobs \\
\hline Cook et al. (1982) & 261.3 & 5.75 & 0.52 & 60.89 & 128 & 8 & Alfalfa hay, corn cobs \\
\hline Faulkner et al. (1982) & 267.3 & 5.52 & 0.69 & 62.68 & 192 & 4 & Corn stalkage \\
\hline Nelson et al. (1982) & 249.3 & 5.06 & 0.19 & 55.16 & 96 & 4 & Alfalfa haylage, wheat straw \\
\hline Nelson et al. (1983) & 249.8 & 4.62 & 0.36 & 60.23 & 64 & 4 & Corn silage, wheat straw \\
\hline Pankaskie et al. (1983) & 331.4 & 7.83 & 0.83 & 61.64 & 136 & 4 & Alfalfa silage, whole corn, whole high moisture corn \\
\hline DeHaan et al. (1984) & 303.4 & 7.91 & 1.27 & 70.65 & 144 & 6 & Corn silage \\
\hline Guyer et al. (1984) & 228.3 & 4.79 & 0.28 & 55.46 & 120 & 6 & Alfalfa silage, corn stalkage \\
\hline Nelson et al. (1984) & 286.7 & 6.75 & 0.59 & 56.00 & 120 & 4 & Alfalfa haylage, corn silage, corn stalks \\
\hline Aines et al. (1985) & 323.6 & 6.60 & 0.81 & 66.09 & 90 & 3 & Corn cobs, corn silage \\
\hline Roth et al. (1986) & 275.7 & 6.43 & 0.66 & 55.23 & 338 & 16 & Alfalfa hay, corn cobs, corn stalks \\
\hline Mader (1987) & 297.7 & 7.34 & 0.98 & 69.51 & 150 & 3 & Corn silage \\
\hline Rush and Van Pelt (1987) & 338.6 & 7.92 & 0.90 & 65.70 & 392 & 12 & Alfalfa haylage, corn silage, cracked or whole corn \\
\hline Goedeken et al. (1988) & 261.2 & 6.87 & 0.47 & 52.01 & 62 & 2 & Alfalfa hay, corn cobs \\
\hline Roth et al. (1988) & 252.4 & 4.61 & 0.33 & 52.83 & 204 & 12 & Corn bran, corn stalkage \\
\hline Klopfenstein and Owen (1988) & 289.2 & 6.84 & 0.75 & 62.26 & - & 7 & $\begin{array}{l}\text { Brome hay, corn cobs, corn stalkage, } \\
\text { cracked corn, soybean hulls }\end{array}$ \\
\hline Klopfenstein et al. (1990) & 275.3 & 6.48 & 0.77 & 58.33 & 288 & 6 & Alfalfa hay, corn silage, wheat straw \\
\hline Dahlquist and Mader (1991) & 309.8 & 8.00 & 1.08 & 70.73 & 433 & 8 & Corn silage \\
\hline Hollingsworth et al. (1991) & 270.1 & 5.93 & 0.57 & 60.00 & 360 & 9 & Corn cobs, prairie hay, sorghum silage \\
\hline Rush et al. (1992) & 289.8 & 6.87 & 1.19 & 73.25 & - & 4 & Alfalfa hay, corn, corn silage \\
\hline Shain et al. (1993) & 278.6 & 8.87 & 0.96 & 72.71 & 60 & 12 & Alfalfa hay, corn, sorghum silage, soybean hulls \\
\hline
\end{tabular}

${ }^{1} \mathrm{SBW}=$ average shrunk body weight, $\mathrm{kg}$.

${ }^{2}$ Number of animals represented.

${ }^{3}$ Number of pen or treatment means used in evaluation of NRC (1996) model level 1 and development of NE adjustment equations.

${ }^{4}$ Main feed ingredients used in growing trial diets.

\section{MATERIALS AND METHODS}

A data set containing 201 pen or treatment means from 31 different growing trials (Table 1) and 154 pen or treatment means from 17 different finishing trials (Table 2) conducted at the University of Nebraska was compiled and used for evaluating gain predictions of the beef cattle model level 1 (NRC, 2000). All experiments with open-lot pens allowed 32 to $42 \mathrm{~m}^{2}$ per steer with 8 to 10 steers per pen. Data determined to be affected by factors not related to dietary energy availability were excluded. The growing and finishing trials used pen-fed cattle and were winter feeding studies conducted in open dirt lots. Determination of the level of the $\mathrm{NE}_{\mathrm{m}}$ and $\mathrm{NE}_{\mathrm{g}}$ adjusters required to achieve accurate prediction of gain used the same data set.

Additional evaluation of NRC (1996) model level 1 ADG predictions used a second data set of 916 cattle fed individually in 15 different finishing trials (Table 3 ) conducted at the University of Nebraska. The NE adjusters required for accurate prediction of $\mathrm{ADG}$ in the individually fed cattle data set were compared with the finishing trials with the pen-fed cattle data set to evaluate the assumption of thermoneutral conditions used in developing diet $\mathrm{NE}$ adjuster equations. The finishing trials used individually fed cattle fed from Calan electronic gates (American Calan, Northwood, $\mathrm{NH}$ ) in barns that were open-faced to the south. The barn pens allowed $2.8 \mathrm{~m}^{2}$ per steer inside the barn with concrete flooring and an open lot outside (an additional $10 \mathrm{~m}^{2}$ per steer).

A Microsoft Excel (Microsoft Corporation, Redmond, WA) spreadsheet was developed to evaluate and refine the NRC (1996) model level 1 predictions of ADG. Equations utilized in prediction of ADG under thermoneutral conditions were:

$$
\begin{aligned}
\mathrm{NE}_{\mathrm{m}}=0.077 \times & \left(\mathrm{SBW}^{0.75}\right) \times(\mathrm{BE}) \times[0.8+0.05 \\
& \times(\mathrm{BCS}-1)] \\
\mathrm{I}_{\mathrm{m}}= & \mathrm{NE}_{\mathrm{m}} \div\left(\mathrm{NE}_{\mathrm{ma}} \times \mathrm{ADTV}\right), \\
\mathrm{RE}= & \left(\mathrm{DMI}-\mathrm{I}_{\mathrm{m}}\right) \times \mathrm{NE}_{\mathrm{ga}}, \text { and }
\end{aligned}
$$


Table 2. Description of finishing trials used in evaluation of the NRC (1996) model level 1 and development of NE adjustment equations

\begin{tabular}{|c|c|c|c|c|c|c|c|}
\hline Trial & SBW $^{1}$ & DMI, kg & $\mathrm{ADG}, \mathrm{kg}$ & TDN, $\%$ & $\mathrm{n}^{2}$ & $\mathrm{n}^{3}$ & Ingredients ${ }^{4}$ \\
\hline Vieselmeyer et al. (1994) & 463.3 & 11.89 & 1.43 & 82.59 & 180 & 36 & Dry rolled corn \\
\hline McCoy et al. $(1995)^{5}$ & 450.3 & 10.26 & 1.73 & 83.70 & 120 & 2 & Dry rolled corn \\
\hline Shain et al. (1995) & 473.7 & 12.78 & 1.70 & 82.59 & 182 & 32 & Dry rolled corn \\
\hline McCoy et al. $(1996)^{5}$ & 437.5 & 10.31 & 1.70 & 82.02 & 32 & 1 & Dry rolled corn \\
\hline Shain et al. (1996) & 464.0 & 12.17 & 1.69 & 82.59 & 374 & 28 & Dry rolled corn \\
\hline $\begin{array}{l}\text { Erickson et al. (1998a; 1998b); } \\
\text { Erickson and Klopfenstein }(2001)^{5,6}\end{array}$ & 424.3 & 9.03 & 1.57 & 82.94 & 96 & 12 & Dry rolled corn \\
\hline Herold et al. $(1998)^{6}$ & 428.6 & 10.20 & 1.70 & 83.64 & 40 & 1 & Dry rolled corn \\
\hline Milton et al. $(1999)^{5,6}$ & 418.4 & 9.30 & 1.52 & 82.59 & 320 & 6 & Dry rolled corn \\
\hline Scott et al. $(1999)^{5,6}$ & 413.1 & 10.02 & 1.50 & 83.36 & 40 & 1 & $\begin{array}{l}\text { Dry rolled corn, high moisture corn, } \\
\text { wet corn gluten feed }\end{array}$ \\
\hline Macken et al. $(2003)^{5,6}$ & 442.1 & 8.98 & 1.58 & 81.45 & 80 & 2 & Dry rolled corn \\
\hline
\end{tabular}

\footnotetext{
${ }^{1}$ Average shrunk body weight, $\mathrm{kg}$.

${ }^{2}$ Number of animals represented.

${ }^{3}$ Number of pen or treatment means used in evaluation of NRC (1996) model level 1 and development of NE adjustment equations.

${ }^{4}$ Main feed ingredients used in finishing trial diets.

${ }^{5}$ Pen or treatment means used in evaluating the effect of environment on predictions of ADG.

${ }^{6} \mathrm{Pen}$ or treatment means used in comparison of $\mathrm{NE}$ adjustment required under good or poor weather conditions.
}

$$
\begin{gathered}
\mathrm{SWG}=13.91 \times \mathrm{RE}^{0.9116} \times(\mathrm{SBW} \\
\times \mathrm{SRW} \div \mathrm{FSBW})^{-0.6837},
\end{gathered}
$$

where SBW = shrunk body weight in $\mathrm{kg} ; \mathrm{BE}=$ breed maintenance requirement multiplier (NRC, 1996), $\mathrm{I}_{\mathrm{m}}=$ intake required for maintenance in $\mathrm{kg}$; $\mathrm{NE}_{\mathrm{ma}}=\mathrm{NE}_{\mathrm{m}}$ available from the diet in $\mathrm{Mcal} / \mathrm{kg}$; $\mathrm{ADTV}=\mathrm{NE}_{\mathrm{ma}}$ modifier for ionophore inclusion (NRC, 1996); RE = retained energy in Mcal/d; $\mathrm{NE}_{\mathrm{ga}}=\mathrm{NE}_{\mathrm{g}}$ available from the diet in Mcal/kg; SWG = shrunk weight gain in $\mathrm{kg} / \mathrm{d}$; SRW = shrunk reference weight (NRC, 1996); and FSBW = final shrunk body weight in kg.

Model inputs were cattle weights, DMI, diet composition, and use of ionophores. Energy density of the diets was determined from published results, including IVDMD, or from diet composition and NRC (1996) feed table TDN values. The NRC (1996) model level 1 equations converted TDN to $\mathrm{NE}_{\mathrm{m}}$ and $\mathrm{NE}_{\mathrm{g}}$.

Unless otherwise indicated, all analyses were conducted under the assumption of thermoneutral conditions for current and previous conditions $\left(20^{\circ} \mathrm{C}\right.$ and no

Table 3. Description of individually fed cattle trials used in evaluation of NRC (1996) model level 1

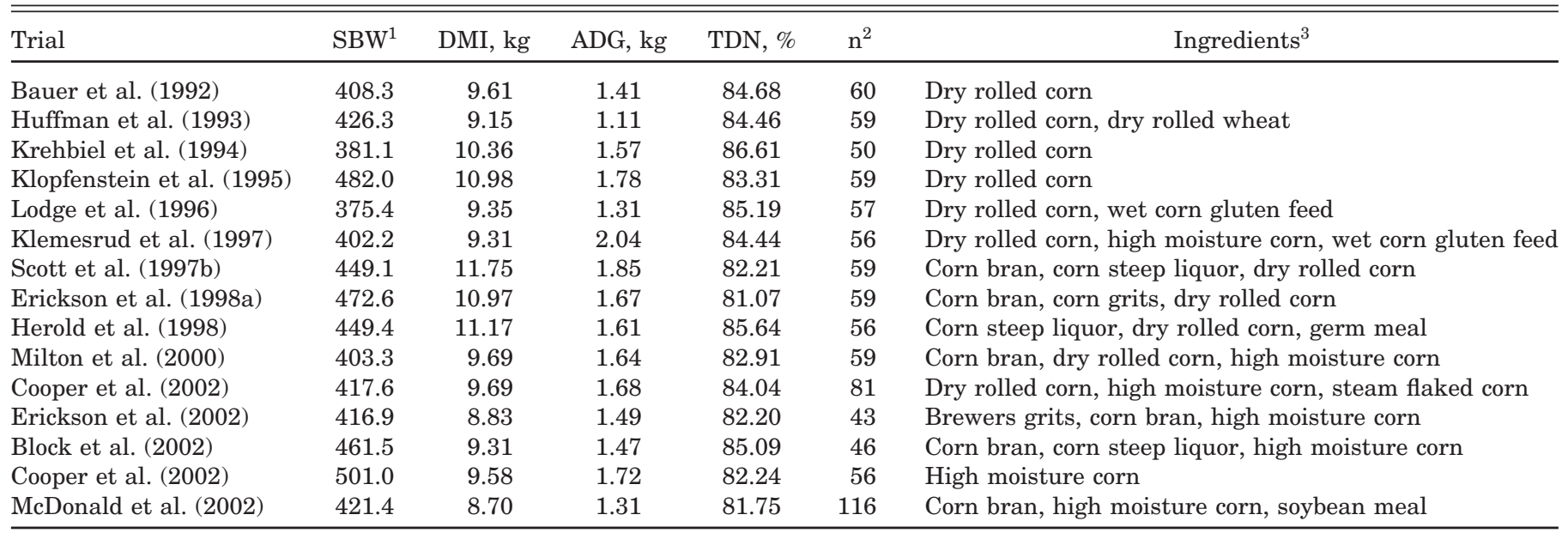

\footnotetext{
${ }^{1}$ Average shrunk body weight, $\mathrm{kg}$.
}

${ }^{2}$ Number of animals represented and used in evaluation of NRC (1996) model level 1.

${ }^{3}$ Main feed ingredients used in individually fed trial diets. 
Table 4. Description of data used in evaluation of NRC (1996) model level 1 and development of NE adjustment equations

\begin{tabular}{|c|c|c|c|c|}
\hline Item & Mean & $\mathrm{SD}$ & Minimum & Maximum \\
\hline \multicolumn{5}{|l|}{ Average weight, $\mathrm{kg}$} \\
\hline Growing, $\mathrm{n}=201$ & 276.3 & 30.1 & 218.4 & 371.9 \\
\hline Finishing, $\mathrm{n}=154$ & 452.2 & 32.5 & 361.0 & 539.7 \\
\hline Individually fed, $\mathrm{n}=916$ & 430.5 & 47.4 & 299.3 & 588.8 \\
\hline \multicolumn{5}{|l|}{$\mathrm{ADG}, \mathrm{kg}$} \\
\hline Growing, $\mathrm{n}=201$ & 0.707 & 0.299 & 0.122 & 1.361 \\
\hline Finishing, $\mathrm{n}=154$ & 1.591 & 0.173 & 1.197 & 2.032 \\
\hline Individually fed, $\mathrm{n}=916$ & 1.565 & 0.350 & 0.167 & 3.104 \\
\hline \multicolumn{5}{|l|}{ DMI, kg } \\
\hline Growing, $\mathrm{n}=201$ & 6.63 & 1.44 & 3.90 & 9.48 \\
\hline Finishing, $\mathrm{n}=154$ & 11.34 & 1.45 & 7.80 & 14.01 \\
\hline Individually fed, $\mathrm{n}=916$ & 9.84 & 1.35 & 5.96 & 14.93 \\
\hline \multicolumn{5}{|l|}{ TDN, $\%$} \\
\hline Growing, $\mathrm{n}=201$ & 61.61 & 7.32 & 42.74 & 75.38 \\
\hline Finishing, $\mathrm{n}=154$ & 82.69 & 0.40 & 82.45 & 84.50 \\
\hline Individually fed, $\mathrm{n}=916$ & 83.58 & 2.42 & 76.26 & 89.88 \\
\hline \multicolumn{5}{|l|}{ Final shrunk BW } \\
\hline Finishing, ${ }^{1} \mathrm{n}=154$ & 546.4 & 37.7 & 414.5 & 621.7 \\
\hline Individually fed, $\mathrm{n}=916$ & 533.5 & 55.0 & 324.0 & 700.0 \\
\hline
\end{tabular}

${ }^{1}$ Value used as final shrunk BW for all growing cattle observations.

wind). Weather data for evaluation of the assumption of thermoneutral conditions were obtained from the High Plains Climate Center, which maintains automated weather data collection stations near the University of Nebraska's Institute of Agriculture and Natural Resource research feedlot at Mead, Nebraska.

Final shrunk body weight (FSBW) for finishing trials was determined from carcass weight and a common carcass dressing percent of $63 \%$. Data regarding FSBW in the growing trials were not available; consequently, the FSBW that was used was equal to the average of the finishing trials $(546 \mathrm{~kg}$ ). When available, marbling scores were used to specify SRW in accordance with NRC (1996); otherwise, slight marbling was assumed. Because BCS data were not available for any of the trials, a BCS of 5 was assumed for all trials. Sensitivity of the NRC (1996) model level 1 prediction of ADG to changes in FSBW, BCS, and the relationship of 4.409 Mcal of DE per kg of TDN was evaluated by increasing or decreasing input values by $10 \%$. There was no evaluation of the relationship of $0.82 \mathrm{Mcal}$ of $\mathrm{ME} / \mathrm{Mcal}$ of $\mathrm{DE}$, because it would yield identical results to the evaluation of $4.409 \mathrm{Mcal}$ of DE/kg of TDN. Regression analysis procedures suggested by Harrison (1990) and Mayer and Butler (1993) were used to evaluate the accuracy, slope $=1$, and intercept $=0$ when observed $(\mathrm{y})$ and predicted $(\mathrm{x})$ values were regressed using SAS (SAS Inst. Inc., Cary, NC), and the precision of ADG prediction. Bias and mean square error of prediction were calculated and partitioned as described by Rice and Cochran (1984).

After evaluation of $\mathrm{ADG}$, the diet $\mathrm{NE}_{\mathrm{m}}$ and $\mathrm{NE}_{\mathrm{g}}$ were adjusted until the predicted and observed ADG agreed. There was equal application of the adjustments to $\mathrm{NE}_{\mathrm{m}}$ and $\mathrm{NE}_{\mathrm{g}}$. Within the NRC (1996) model level 1, there are separate adjusters for $\mathrm{NE}_{\mathrm{m}}$ and $\mathrm{NE}_{\mathrm{g}}$. Upper and lower limits on these adjusters are 120 and $80 \%$, respectively, for predicted diet $\mathrm{NE}_{\mathrm{m}}$ and $\mathrm{NE}_{\mathrm{g}}$. It was possible to exceed these limits through use of model level 1 equations, but not when using the NRC (1996) model level 1 software. The resulting adjuster levels were then regressed against observed $\mathrm{ADG}$, total TDN intake $(\mathrm{kg} /$ $\mathrm{d}$ ), and TDN concentration ( $\mathrm{kg} / \mathrm{kg}$ of DM) using PROC NLIN procedures of SAS to develop equations predicting the adjuster required for accurate ADG prediction.

A subset of the finishing trial studies of the pen-fed cattle data set for which weather data could be obtained was used to compare the effects of anecdotally good (warm and dry; $\mathrm{n}=3$ ) or poor (cold and wet; $\mathrm{n}=16$ )

Table 5. Distribution of observations by energy density for Garrett (1980) and University of Nebraska (UNL) data sets, \% of total

\begin{tabular}{llccc}
\hline \hline & \multicolumn{4}{c}{ ME level, Mcal/kg } \\
\cline { 2 - 5 } Data set & $<1.9$ & $1.9-2.6$ & $2.6-2.9$ & $>2.9$ \\
\hline Garrett (1980) & 1 & 22 & 65 & 12 \\
UNL growing and finishing data set, $\mathrm{n}=355$ & 7.89 & 44.79 & 3.94 & 43.38 \\
UNL individually fed data set, $\mathrm{n}=916$ & 0 & 0 & 3.82 & 96.18 \\
\hline
\end{tabular}


Table 6. Sensitivity of ADG prediction to changes in BCS, final shrunk BW (FSBW), TDN to $\mathrm{DE}$ conversion, $\mathrm{NE}_{\mathrm{m}}$, and $\mathrm{NE}_{\mathrm{g}}$

\begin{tabular}{lccccc}
\hline \hline & & \multicolumn{3}{c}{ Change in ADG prediction, \% } \\
\cline { 3 - 5 } Item & Change in item & Growing & Finishing & Combined $^{1}$ & Individually fed $^{2}$ \\
\hline \multirow{2}{*}{ BCS } & $+10 \%$ & -2.78 & -0.96 & -1.53 & -1.11 \\
& $-10 \%$ & 2.76 & 0.95 & 1.52 & 1.11 \\
FSBW & $+10 \%$ & 6.73 & 6.73 & 6.73 & 6.73 \\
& $-10 \%$ & -6.95 & -6.95 & -6.95 & -6.9 \\
TDN to DE conversion & $+10 \%$ & 36.28 & 18.3 & 23.95 & 18.87 \\
& $-10 \%$ & -35.56 & -19.25 & -24.38 & -19.81 \\
$\mathrm{NE}_{\mathrm{m}}$ & $+10 \%$ & 10.02 & 3.47 & 5.53 & 4.02 \\
& $-10 \%$ & -12.44 & -4.25 & -6.83 & -4.94 \\
$\mathrm{NE}_{\mathrm{g}}$ & $+10 \%$ & 9.08 & 9.08 & 9.08 & 9.08 \\
& $-10 \%$ & -9.16 & -9.16 & -9.16 & -9.16 \\
\hline
\end{tabular}

${ }^{1}$ Combined growing and finishing trials used in evaluation of the NRC (1996) model level 1 and development of $\mathrm{NE}$ adjustment equations.

${ }^{2}$ Individually fed trials used in evaluation of NRC (1996) model level 1 before and after application of NE adjustment equations.

winter weather conditions on the required $\mathrm{NE}_{\mathrm{m}}$ and $\mathrm{NE}_{\mathrm{g}}$ adjustment for accurate $\mathrm{ADG}$ prediction. A second subset $(\mathrm{n}=22)$ of the finishing trials of the pen-fed cattle data set, for which daily feed intake data were available, allowed comparison of $\mathrm{ADG}$ predictions to observed ADG after application of various portions of the environmental effects submodel (NRC, 1996). For this evaluation, use of weather data averaged over the entire feeding period reflects the long-term average effects of environment, whereas use of daily weather data is more sensitive to transient environmental fluctuations.

To account for effects of environment, $\mathrm{NE}_{\mathrm{m}}$ requirements increased in response to the effects of acclimation and cold stress. The acclimation effect increased the $0.077 \mathrm{Mcal} /\left(\mathrm{d} \cdot \mathrm{SBW}^{0.75}\right)$ used in determining the maintenance requirement by $0.0007 \mathrm{Mcal} /\left(\mathrm{d} \cdot \mathrm{SBW}^{0.75}\right)$ for each $1^{\circ} \mathrm{C}$ that the average temperature for the previous 28 $\mathrm{d}$ was below $20^{\circ} \mathrm{C}$. Assumptions of a BCS of 5 , an average hide thickness, an effective hair depth of $1.27 \mathrm{~cm}$, and some mud on the lower body modified the NRC (1996) model equations used to compute lower critical temperature and the effect of cold stress to the following:

$$
\begin{gathered}
\mathrm{LCT}=39-0.85 \times \mathrm{IN} \times \mathrm{HE}, \\
\mathrm{IN}=15.2288-0.2368 \mathrm{Wind}, \\
\mathrm{HE}=(\mathrm{MEI}-\mathrm{RE}) \div \mathrm{SA} \\
\mathrm{SA}=0.09 \times \mathrm{SBW}^{0.75}, \text { and } \\
\mathrm{NE}_{\mathrm{mcs}}=\mathrm{NE}_{\mathrm{ma}} \div \mathrm{ME} \times \mathrm{SA} \times\left(\mathrm{LCT}-\mathrm{T}_{\mathrm{c}}\right) \div \mathrm{IN},
\end{gathered}
$$

where LCT $=$ lower critical temperature in ${ }^{\circ} \mathrm{C}$; IN = insulation in ${ }^{\circ} \mathrm{C} /\left(\mathrm{Mcal} \times \mathrm{m}^{2} \times \mathrm{d}\right)$; $\mathrm{HE}=$ heat production in Mcal/d; Wind = wind speed in $\mathrm{km} / \mathrm{h}$; MEI = ME intake in $\mathrm{Mcal} / \mathrm{d} ; \mathrm{SA}=$ surface area in $\mathrm{m}^{2} ; \mathrm{NE}_{\mathrm{mcs}}=\mathrm{NE}_{\mathrm{m}}$ for cold stress; $\mathrm{ME}=\mathrm{ME}$ available from the diet in Mcal/ $\mathrm{kg}$; and $\mathrm{T}_{\mathrm{c}}=$ current temperature in ${ }^{\circ} \mathrm{C}$.

Due to the relatively narrow range of values for the 2 subsets, statistical analysis was limited to mean comparisons using SAS (SAS Inst., Inc.).

\section{RESULTS AND DISCUSSION}

Tables 1, 2, 3, and 4 describe the data sets used in evaluating the NRC (1996) model level 1 and development of the diet $\mathrm{NE}_{\mathrm{m}}$ and $\mathrm{NE}_{\mathrm{g}}$ adjustment equations. Documentation of implant or ionophore use occurred with only 6 and 62 growing trial treatment means, respectively. All finishing trial treatments included the use of implants and ionophores. With individually fed cattle, documentation of implant and ionophore use occurred in 860 and 787 cattle, respectively.

The relationship of TDN to DE was about $4.409 \mathrm{Mcal}$ of DE/kg of TDN (NRC, 1996), but may vary with the nutrient composition of the feed (NRC, 2001). The relationship of $\mathrm{DE}$ to $\mathrm{ME}$ was about $0.8 \mathrm{Mcal}$ of $\mathrm{ME} / \mathrm{Mcal}$ (NRC, 1996), but may vary with intake, age of animal, and feed source (Agricultural Research Council, 1980; Commonwealth Scientific and Industrial Research Organization, 1990; as cited by NRC, 1996). Setting the conversion of TDN to DE and DE to ME at $4.409 \mathrm{Mcal}$ of $\mathrm{DE} / \mathrm{kg}$ of TDN and $0.82 \mathrm{Mcal}$ of $\mathrm{ME} / \mathrm{Mcal}$ of DE, respectively, transfers variation in its relationships into the equations that predicted diet $\mathrm{NE}_{\mathrm{m}}$ and $\mathrm{NE}_{\mathrm{g}}$ from ME. Therefore, the range in diet energy densities used in predicting diet $\mathrm{NE}_{\mathrm{m}}$ and $\mathrm{NE}_{\mathrm{g}}$ from $\mathrm{ME}$ was particularly important.

Garrett (1980) developed equations to predict diet $\mathrm{NE}_{\mathrm{m}}$ and $\mathrm{NE}_{\mathrm{g}}$ from a data set with unequally distributed and high-energy diets, whereas the growing and finishing cattle data set used in this evaluation had diets with greater range in energy densities (Table 5). The growing and finishing cattle data set was more evenly distributed between high ( $>2.9 \mathrm{Mcal}$ of $\mathrm{ME} / \mathrm{kg}$ 


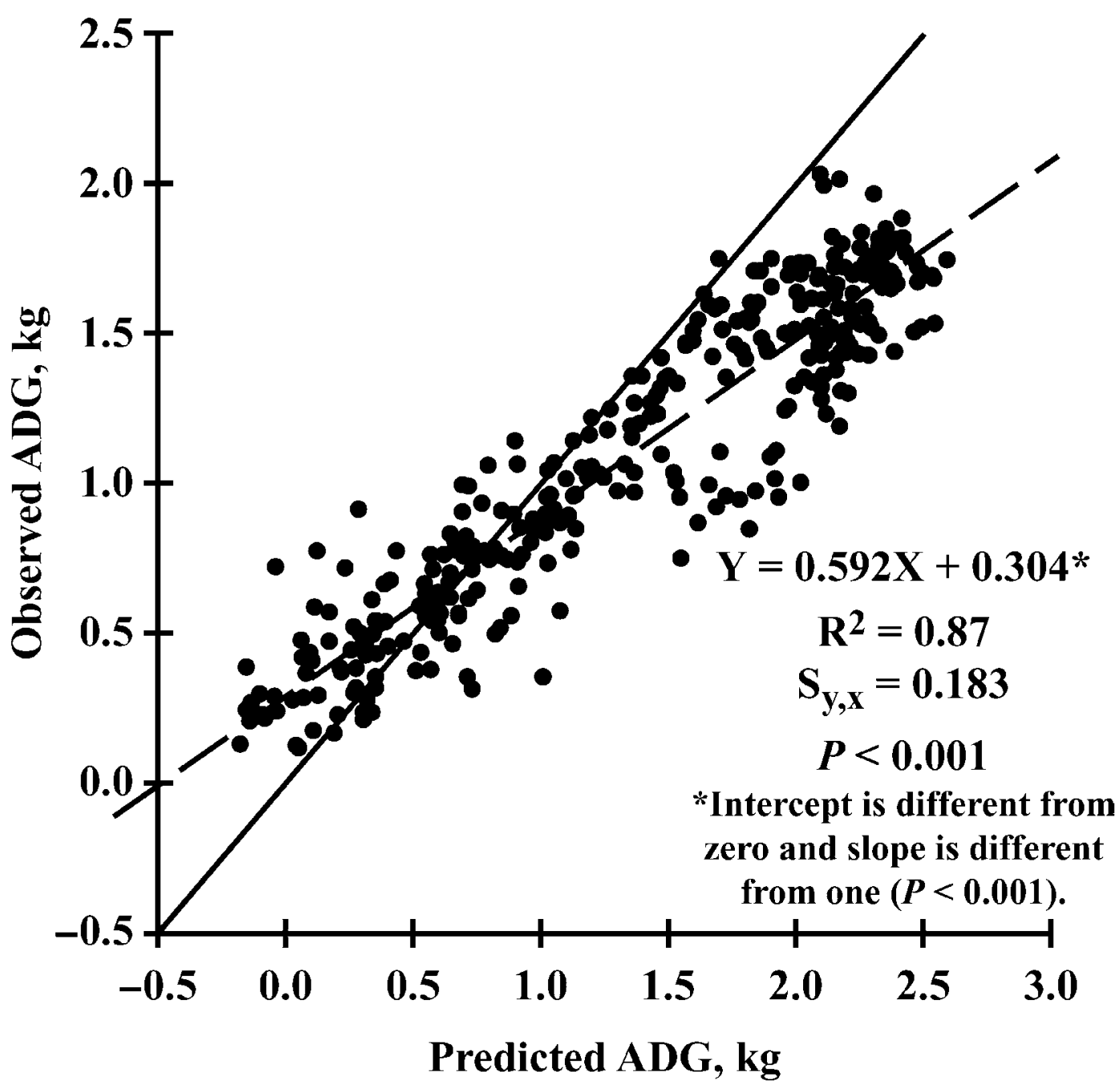

Figure 1. Accuracy of NRC (1996) model level 1 ADG predictions. Each point represents a pen or treatment mean $(\mathrm{n}=355)$. The solid line represents the isopleth, and the dashed line represents the fitted regression (the regression equation is shown).

of DM) and moderately low (1.9 to $2.6 \mathrm{Mcal}$ of $\mathrm{ME} / \mathrm{kg}$ of DM) energy diets, but had relatively few observations at moderately high (2.6 to $2.9 \mathrm{Mcal}$ of $\mathrm{ME} / \mathrm{kg}$ of $\mathrm{DM})$ and very low ( $<1.9 \mathrm{Mcal}$ of ME/kg of DM) energy diets. The individually fed cattle data set was poorly distributed with regard to diet energy density with almost all observations occurring within the high energy $(<2.9$ Mcal of ME/kg of DM) category.

The sensitivity analysis of ADG predictions to changes in BCS, FSBW, TDN to DE conversion, and diet $\mathrm{NE}_{\mathrm{m}}$ and $\mathrm{NE}_{\mathrm{g}}$ values found predictions to be relatively insensitive to changes in FSBW, BCS, and diet $\mathrm{NE}_{\mathrm{m}}$, moderately sensitive to changes in diet $\mathrm{NE}_{\mathrm{g}}$, and very sensitive to changes in TDN to DE conversion (Table 6). Changes in DE to ME conversion have the same effect as changes in TDN to DE conversion. However, BCS, FSBW, TDN to DE conversion, DE to ME conversion, and diet $\mathrm{NE}_{\mathrm{m}}$ and $\mathrm{NE}_{\mathrm{g}}$ values are unlikely to have the same coefficients of variation.

Prediction of $\mathrm{ADG}$ in the growing and finishing trial data set was relatively precise with an $\mathrm{s}_{\mathrm{y} \cdot \mathrm{x}}$ of 0.183 $\mathrm{kg}$, but inaccurate, because the relationship between predicted and observed ADG was different $(P<0.001)$ from the isopleth $(y=x$; Figure 1). Predictions of ADG were accurate at $0.745 \mathrm{~kg}$ with under- and overprediction occurring when ADG was below and above this value, respectively. The mean bias was $0.24 \mathrm{~kg}$ with root mean square error of prediction of $0.44 \mathrm{~kg}$ with bias, deviation of slope from unity, and lack of perfect correlation accounting for 29,54 , and $17 \%$ of the inaccuracy, respectively. The prediction of $A D G$ in the individually fed cattle data set was less precise with an $\mathbf{s}_{\mathrm{y} . \mathrm{x}}$ of $0.277 \mathrm{~kg}$, and inaccurate, because the relationship between predicted and observed ADG was different $(P$ $<0.001)$ from the isopleth $(y=x$; Figure 2). Predictions of ADG were accurate at $1.139 \mathrm{~kg}$ with under- and overprediction occurring when ADG was below and above this value, respectively. Mean bias was $0.24 \mathrm{~kg}$ with root mean square error of prediction of $0.39 \mathrm{~kg}$ with bias, deviation of slope from unity, and lack of perfect correlation accounting for 39,10 , and $51 \%$ of inaccuracy, respectively. It is understandable that greater 


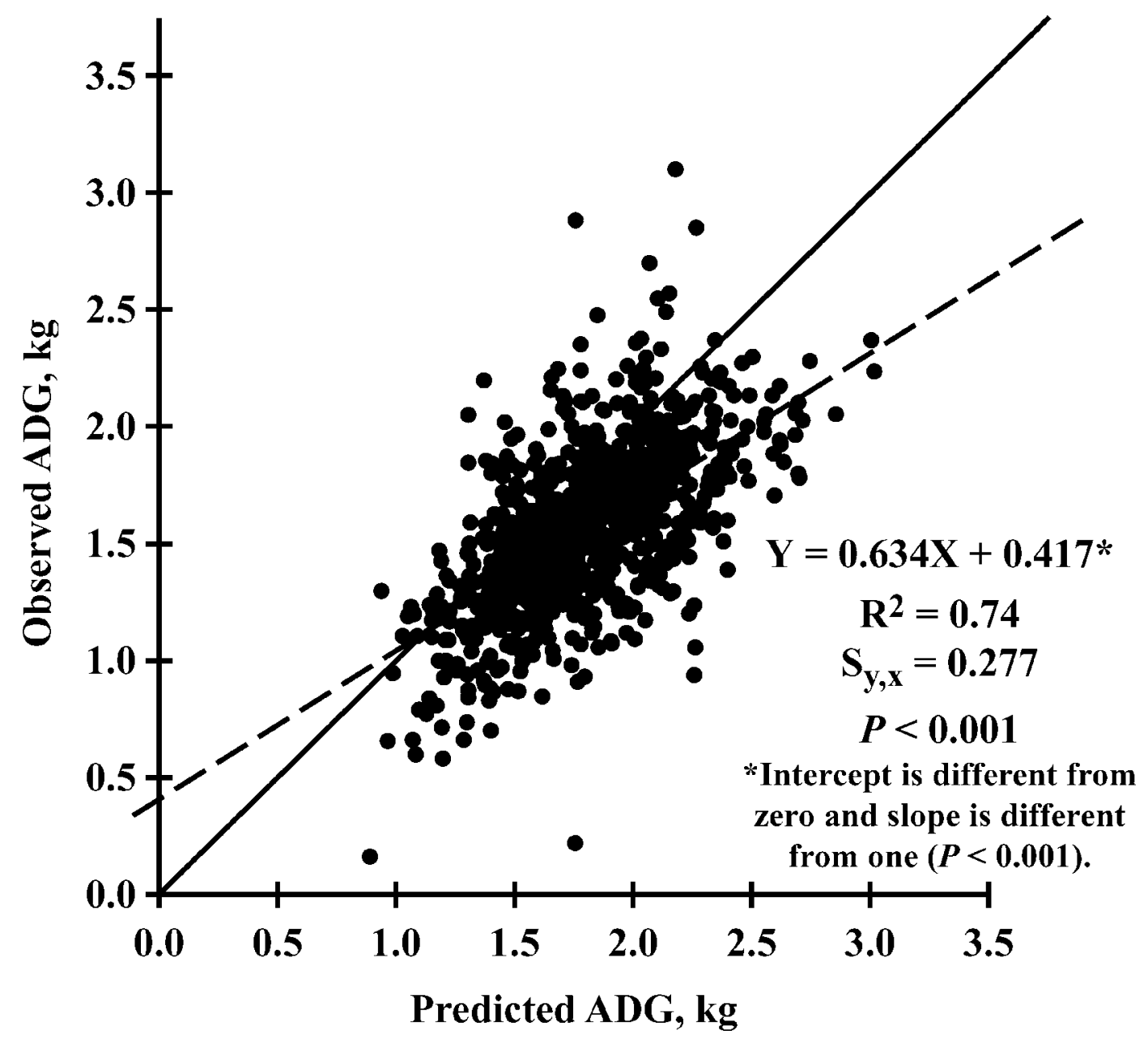

Figure 2. Accuracy of NRC (1996) model level 1 ADG predictions with the individually fed cattle data set. Each point represents an individually fed animal $(\mathrm{n}=916)$. The solid line represents the isopleth, and the dashed line represents the fitted regression (the regression equation is shown).

variation in gain exists with individual animal data than with pen data averaged over several animals with resulting loss in the degree of detail present in the data.

With the individually fed cattle trials, an average NE adjuster of 0.906 was required for accurate prediction of ADG. In contrast, the pen-fed finishing trials required a greater $(P<0.001)$ level of adjustment with an average $\mathrm{NE}$ adjuster of 0.820 for accurate prediction of $\mathrm{ADG}$, indicating greater initial overprediction of ADG by the NRC (1996) model level 1. The southern-exposure open barns containing the Calan electronic gates afforded the individually fed cattle a level of protection from environmental extremes of wind and precipitation not available to the pen-fed cattle. Although both groups of cattle had equal exposure to fluctuations in temperature, it would seem that the extra protection available to individually fed cattle is responsible for the difference in $\mathrm{NE}$ adjuster required and the level of ADG overprediction observed. However, a difference in the management of the 2 groups of cattle during the feeding trials complicates this comparison. With the individually fed cattle, cattle were adapted to high-concentrate finishing diets by gradually increasing the amount of the final finishing diet offered until cattle achieved ad libitum intake. In contrast, cattle in the pen-fed finishing trials were adapted to the final finishing diets by gradual decreases in diet forage content. Insufficient data were available to account for the effects of greater forage levels during the adaptation phase of the pen-fed finishing cattle studies. Consequently, use of the final finishing diet energy values only over the entire feeding period would contribute to overprediction of ADG. Whereas the adaptation program used with individually fed cattle studies has no clear effect on prediction of $\mathrm{ADG}$, it is unclear what portion of the difference in $\mathrm{NE}$ adjuster required for the 2 groups of cattle is due to environment or management differences.

Use of thermoneutral conditions for all predictions would maximize the prediction of ADG and contribute to inaccurate prediction any time that environmental conditions were severe enough to decrease ADG. Therefore, overprediction of ADG can occur with invalid assumption of thermoneutral conditions. More effective modeling of environmental impacts on $\mathrm{ADG}$ by growing 
Table 7. Equations ${ }^{1}$ to adjust NE based on observed ADG, TDN intake, and TDN concentration

\begin{tabular}{lllllll}
\hline \hline Item used as X & $\mathrm{a}$ & $\mathrm{SE}$ & $\mathrm{k}$ & $\mathrm{SE}$ & $\mathrm{b}$ & $\mathrm{SE}$ \\
\hline ADG, kg & 0.7011 & 0.0238 & 0.8562 & 0.0577 & 0.8042 & 0.0121 \\
TDN intake, kg/d & 4.795 & 0.744 & 0.3689 & 0.0279 & 0.8233 & 0.0121 \\
TDN concentration, $\mathrm{kg} / \mathrm{kg}$ of DM & 357 & 101 & 5.449 & 0.256 & 0.8138 & 0.0106 \\
\hline
\end{tabular}

${ }^{1}$ Equations are of the form: $\mathrm{y}=\mathrm{a} \times 10^{(-\mathrm{kX})}+\mathrm{b}$.

cattle would bring observed and predicted ADG into closer agreement for rapidly growing cattle where $\mathrm{ADG}$ was overpredicted, but would result in greater discrepancies between observed and predicted ADG for slowly growing cattle where $\mathrm{ADG}$ was under predicted.

Because of considerable mud, the poor feeding conditions for finishing trials conducted during the 19971998 and 1998-1999 feeding seasons required a NE adjustment of 0.911 for accurate prediction of ADG. For the much drier feeding conditions for finishing trials conducted during the 1999-2000 feeding season, a lesser $(P<0.01) \mathrm{NE}$ adjustment of 0.997 was required for accurate prediction of ADG. These anecdotal observations suggest a relatively substantial portion of variation in NE adjustment required is attributable to the effect of environment on maintenance energy requirements.

A subset of the pen-fed data was used to determine the effects of accounting for acclimation and cold stress in the NRC (1996) model level 1. Observed ADG for the data set was $1.559 \mathrm{~kg}$. The model has 2 distinct mechanisms to account for environmental influences (primarily temperature): acclimation and cold stress. Before application of acclimation and cold stress effects, ADG predicted using actual DMI was greater $(P<0.01)$ than observed at $1.755 \mathrm{~kg}$. Accumulation of acclimation effects on a daily basis vs. use of data averaged over each of the respective trials resulted in predictions of ADG that were identical. This indicates that environmental acclimation effects on predicted maintenance energy requirements are relatively insensitive to the time scale used for evaluation. After inclusion of acclimation effects, prediction of ADG was $1.667 \mathrm{~kg}$ and remained greater $(P<0.01)$ than observed ADG.

Using data averaged over the respective trials, cattle were predicted to have experienced cold stress in only one trial. For this trial, predicted ADG after application of acclimation effects was $1.551 \mathrm{~kg}$ and inclusion of cold stress effects resulted in predicted ADG becoming 1.516 $\mathrm{kg}$. In contrast, accounting for cold stress effects on a daily basis resulted in cattle in all feeding trials being predicted to have experienced some degree of cold stress. The number of days for which cold stress was predicted to have been experienced ranged from 29 to $78 \mathrm{~d}$ with an average of $51 \mathrm{~d}$. Predicted ADG after accounting for the predicted effect of cold stress at 1.598 $\mathrm{kg}$ was not different $(P=0.28)$ from observed $\mathrm{ADG}$ at $1.559 \mathrm{~kg}$.
These results do not necessarily indicate that the environmental effects submodel is correct and that its use will result in increased accuracy when predicting ADG. As stated earlier, use of thermoneutral conditions for all predictions would maximize the prediction of $\mathrm{ADG}$ and contribute to overprediction any time environmental conditions were severe enough to decrease ADG. Application of the environmental effects submodel improved accuracy of $\mathrm{ADG}$ prediction with finishing trial results in which ADG was overpredicted. However, ADG prediction would worsen with the growing trials in which ADG was underpredicted. The results from application of the cold stress effects using daily data or data averaged over the trial show clear differences in how the time scale used in modeling can influence predictions.

The relationship between observed ADG and NE adjustment required for accurate prediction of ADG was relatively weak but had little residual variation $\left(R^{2}=\right.$ $0.325, \mathrm{~s}_{\mathrm{y} . \mathrm{x}}=0.136, P<0.001$; Table 7). This relationship was investigated to allow determination of $\mathrm{NE}$ adjuster required when information regarding diet energy density and intake are unavailable. A stronger relationship existed between TDN intake and NE adjustment required for accurate prediction of $\mathrm{ADG}\left(\mathrm{R}^{2}=0.714, \mathrm{~s}_{\mathrm{y} \cdot \mathrm{x}}=\right.$ $0.157, P<0.001$; Table 7). However, this relationship had larger residual variation. Additionally, total DMI confounded the use of TDN intake in predicting the required adjustment to NE. Having TDN intake confounded by DMI may be advantageous for predicting the NE adjustment required when feeding high-energy diets with substantial intake variation and departure from typical intake levels. The best relationship with the lowest residual variation was between TDN concentration and required NE adjustment $\left(\mathrm{R}^{2}=0.754, \mathrm{~s}_{\mathrm{y} . \mathrm{x}}=\right.$ $0.126, P<0.001$; Table 7). Use of TDN concentration to determine the level of $\mathrm{NE}$ adjustment required will be most responsive to changes in TDN concentration with low-energy diets. This equation may best address the issue of greater degree of inaccuracy in ADG prediction by the NRC (1996) model level 1 when lower energy diets are fed (Patterson et al., 2000). If the cause of inaccurate $\mathrm{ADG}$ prediction is related to diet energy level, use of diet energy level in adjusting ADG prediction is the most relevant basis for correction.

There is a need for caution in use of these equations to improve prediction of ADG by the NRC (1996) model level 1 . There were differences in the NE adjuster re- 
quired for accurate $\mathrm{ADG}$ prediction observed with the different data sets and subsets, indicating some uniqueness to the data set from which the NE adjusters were derived. There are numerous observations at high observed ADG, high TDN intake, and high TDN concentration in the growing and finishing data set used and reason for confidence in the ability of the $\mathrm{NE}$ adjuster equations to improve predictions of $\mathrm{ADG}$ at this end of the scale. However, the ability of the NE adjustment equations to improve prediction of ADG with low observed ADG, low TDN intake, and low TDN concentration is less certain due to fewer observations, and greater responsiveness to small changes in observed ADG, TDN intake, and TDN concentration. Lastly, the range of $\mathrm{NE}$ adjustment suggested by these equations extends beyond the 0.8 to 1.2 times normal adjustment limit imposed by the NRC (1996) model level 1 software. It is possible to exploit the environment submodel of the NRC (1996) model level 1 to extend the range for adjustment of $\mathrm{NE}$ values by altering the requirement for $\mathrm{NE}_{\mathrm{m}}$.

\section{IMPLICATIONS}

Modification of models that predict beef cattle performance to improve the accuracy of prediction has value for cattle management and evaluation by producers. Even inaccurate models are of value if they represent real-life situations and are informative of both the extent and limitations of current knowledge. The results of this study, especially the relationship found with total digestible nutrient concentration, provide a means of improving the accuracy of average daily gain predictions by suggesting adjustments to net energy values, but also indicate a need for further research with regard to modeling energy use by beef cattle, including the appropriate time scale to account for various impacts on performance.

\section{LITERATURE CITED}

Aines, G., T. Klopfenstein, and B. Britton. 1985. Thin stillage: Potential use in ruminant diets. Pages 62-65 in 1985 Nebraska Beef Report, MP 48. Univ. Nebraska, Lincoln.

Bauer, M., R. Britton, R. Stock, T. Klopfenstein, and D. Yates. 1992. Laidlomycin propionate and acidosis. Pages 46-48 in $1992 \mathrm{Ne}-$ braska Beef Report, MP 58. Univ. Nebraska, Lincoln.

Block, H. C. 1999. Target finishing beef steers and 1996 NRC beef model evaluation. M.S. Thesis, Univ. Saskatchewan, Saskatoon, Canada.

Block, H., C. Macken, T. Klopfenstein, R. Cooper, and R. Stock. 2002. Crude protein and wet corn gluten feed levels for steam flaked corn finishing diets. Pages 68-71 in 2002 Nebraska Beef Report, MP 79-A. Univ. Nebraska, Lincoln.

Block, H. C., J. J. McKinnon, A. F. Mustafa, and D. A. Christensen. 2001. Evaluation of the 1996 NRC beef model under western Canadian environmental conditions. J. Anim. Sci. 79:267-275.

Brandt, B., and T. Klopfenstein. 1983. Alfalfa and bypass protein with ammoniated corn residues. Pages 23-26 in 1983 Nebraska Beef Report, MP 44. Univ. Nebraska, Lincoln.
Cook, F., D. Brink, T. Klopfenstein, J. Merrill, R. Stock, and M. McDonnell. 1982. Hydroxide treatment of cobs. Pages 38-39 in 1982 Nebraska Beef Report, MP 43. Univ. Nebraska, Lincoln.

Cooper, R., T. Milton, and T. Klopfenstein. 2000. Phase-feeding metabolizable protein for finishing steers. Pages $63-65$ in 2000 Nebraska Beef Report, MP 73-A. Univ. Nebraska, Lincoln.

Cooper, R. J., C. T. Milton, T. J. Klopfenstein, and D. J. Jordan. 2001. Effect of corn processing on degradable intake protein requirement of finishing cattle. J. Anim. Sci. 80:242-247.

Dahlquist, J., and T. Mader. 1991. Facility and environment effects on growing steer feedlot performance. Pages 17-19 in 1991 Nebraska Beef Report, MP 56. Univ. Nebraska, Lincoln.

DeHaan, K., T. Klopfenstein, and B. Britton. 1984. Improving forage use with buffers. Pages 35-37 in 1984 Nebraska Beef Report, MP 47. Univ. Nebraska, Lincoln.

Erickson, G., M. Klemesrud, T. Milton, and T. Klopfenstein. 1998a. Phosphorus requirement of finishing yearlings. Pages 78-80 in 1998 Nebraska Beef Report, MP 69-A. Univ. Nebraska, Lincoln.

Erickson, G., T. Klopfenstein, T. Milton, and R. Mass. 2000. Effect of increasing dietary corn silage on performance, digestibility and nitrogen mass balance in the feedlot. Pages 68-71 in 2000 Nebraska Beef Report, MP 73-A. Univ. Nebraska, Lincoln.

Erickson, G., T. Klopfenstein, D. Walters, and G. Lesoing. 1998b. Nutrient balance of nitrogen, organic matter, phosphorus and sulfur in the feedlot. Pages 86-87 in 1998 Nebraska Beef Report, MP 69-A. Univ. Nebraska, Lincoln.

Erickson, G. E., and T. J. Klopfenstein. 2001. Managing N inputs and the effect on $\mathrm{N}$ losses following excretion in open-dirt feedlots in Nebraska. In Optimizing Nitrogen Management in Food and Energy Production and Environmental Protection: Proc. 2nd Int. Nitrogen Conf. Science and Policy. The Scientific World 1(S2):830-835.

Erickson, G. E., T. J. Klopfenstein, C. T. Milton, D. Brink, M. W. Orth, and K. M. Whittet. 2002. Phosphorus requirement of finishing feedlot calves. J. Anim. Sci. 80:1690-1695.

Faulkner, D., M. McDonnell, T. Klopfenstein, and W. Sahs. 1982. Effect of cornstalk quality and monensin. Pages 42-43 in 1982 Nebraska Beef Report, MP 43. Univ. Nebraska, Lincoln.

Fernandez, S., B. Oliveros, T. Klopfenstein, R. Britton, and J. Merrill. 1985. Ammoniation of wheat straw and corn stover. Pages 69-70 in 1985 Nebraska Beef Report, MP 48. Univ. Nebraska, Lincoln.

Fox, D. G., L. O. Tedeschi, T. P. Tylutki, J. B. Russell, M. E. Van Amburgh, L. E. Chase, A. N. Pell, and T. R. Overton. 2004. The Cornell Net Carbohydrate and Protein System model for evaluating herd nutrition and nutrient excretion. Anim. Feed Sci. Technol. 112:29-78.

Garrett, W. N. 1980. Energy utilization by growing cattle as determined and 72 comparative slaughter experiments. Pages 3-7 in Energy Metabolism: Proc. Eighth Symp. Energy Metabolism, Cambridge, MA. L. E. Mount, ed. Butterworth Publishers Inc., Woburn, MA.

Goedeken, F., T. Klopfenstein, and R. Stock. 1986. Liquid suspensions of bypass proteins. Pages 56-57 in 1986 Nebraska Beef Report, MP 50. Univ. Nebraska, Lincoln.

Goedeken, F., T. Klopfenstein, and R. Stock. 1988. Feather meal and blood meal in liquid and pasture supplements. Pages 40-42 in 1988 Nebraska Beef Report, MP 53. Univ. Nebraska, Lincoln.

Guyer, P., D. Faulkner, T. Klopfenstein, J. Merrill, and W. Sahs. 1983. Effect of variety, irrigation, protein supplementation. Pages 21-22 in 1983 Nebraska Beef Report, MP 44. Univ. Nebraska, Lincoln.

Guyer, P., T. Klopfenstein, J. Merrill, and W. Sahs. 1984. Corn stalkage supplements. Pages 24-25 in 1984 Nebraska Beef Report, MP 47. Univ. Nebraska, Lincoln.

Harrison, S. R. 1990. Regression of the model on real-system output: An invalid test of model validity. Agric. Syst. 34:183-190.

Herold, D., M. Klemesrud, T. Klopfenstein, T. Milton, and R. Stock. 1998. Solvent-extracted germ meal, corn bran and steep liquor 
blends for finishing steers. Pages 50-53 in 1998 Nebraska Beef Report, MP 69-A. Univ. Nebraska, Lincoln.

Hollingsworth, K., T. Klopfenstein, and M. Sindt. 1991. Supplementing growing calves with feather meal cubes. Pages 25-27 in 1991 Nebraska Beef Report, MP 56. Univ. Nebraska, Lincoln.

Huffman, R., T. Klopfenstein, R. Stock, R. Britton, and L. Roth. 1993. Lactobacillus acidophilus (MCI811) and subacute ruminal acidosis. Pages 60-63 in 1993 Nebraska Beef Report, MP 59-A. Univ. Nebraska, Lincoln.

Klemesrud, M., T. Klopfenstein, A. Lewis, and R. Stock. 1997. Lysine requirements for feedlot cattle. Pages 65-67 in 1997 Nebraska Beef Report, MP 67-A. Univ. Nebraska, Lincoln.

Klopfenstein, T., F. Goedekin, B. Brandt, B. Britton, and M. Nelson. 1985. Corn bran as high fiber energy supplement. Pages 49-51 in 1985 Nebraska Beef Report, MP 48. Univ. Nebraska, Lincoln.

Klopfenstein, T., R. Huffman, and R. Stock. 1995. Effect of Lactobacillus acidophilus on subacute acidosis and cattle performance. Pages 37-38 in 1995 Nebraska Beef Report, MP 62-A. Univ. Nebraska, Lincoln.

Klopfenstein, T., and F. Owen. 1988. Soybean hulls - an energy supplement for ruminants. Pages 34-38 in 1988 Nebraska Beef Report, MP 53. Univ. Nebraska, Lincoln.

Klopfenstein, T., M. Sindt, and R. Stock. 1990. Ammoniated wheat straw for wintering calves. Pages 49-50 in 1990 Nebraska Beef Report, MP 55. Univ. Nebraska, Lincoln.

Krehbiel, C., D. Shain, C. Richards, G. Ham, R. McCoy, R. Stock, T. Klopfenstein, and R. Britton. 1994. Effect of fat on subacute acidosis in finishing cattle fed corn diets. Pages 48-50 in 1994 Nebraska Beef Report, MP 61-A. Univ. Nebraska, Lincoln.

Lewis, M., J. Merrill, J. Whittier, T. Klopfenstein, R. Britton, and P. Guyer. 1986. Husklage for growing calves. Pages 53-55 in 1986 Nebraska Beef Report, MP 50. Univ. Nebraska, Lincoln.

Lodge, S., R. Stock, T. Klopfenstein, D. Shain, and D. Herold. 1996. Evaluation of wet distillers byproducts composite for finishing ruminants. Pages 63-64 in 1996 Nebraska Beef Report, MP 66-A. Univ. Nebraska, Lincoln.

Macken, C., G. Erickson, T. Milton, T. Klopfenstein, and H. Block. 2003. Effects of starch endosperm type and corn processing method on feedlot performance, nutrient digestibility and ruminal fermentation of high-grain diets. Pages 32-34 in $2003 \mathrm{Ne}-$ braska Beef Report, MP 80-A. Univ. Nebraska, Lincoln.

Mader, T. 1987. Microbial inoculants for corn silage. Pages 63-65 in 1987 Nebraska Beef Report, MP 52. Univ. Nebraska, Lincoln.

Mayer, D. G., and D. G. Butler. 1993. Statistical validation. Ecol. Model. 68:21-32.

McCoy, R., R. Stock, T. Klopfenstein, M. Klemesrud, and G. White. 1996. Effect of energy source and escape protein on receiving and finishing performance and health of calves. Pages 57-60 in 1996 Nebraska Beef Report, MP 66-A. Univ. Nebraska, Lincoln.

McCoy, R., R. Stock, T. Klopfenstein, D. Shain, and G. White. 1995. Effect of wet corn gluten feed and escape protein on receiving and finishing performance and health of calves. Pages 28-30 in 1995 Nebraska Beef Report, MP 62-A. Univ. Nebraska, Lincoln.

McDonald, R. A., T. J. Klopfenstein, G. E. Erickson, C. N. Macken, and K. M. Whittet. 2002. Using allantoin in spot urine samples to predict bacterial protein production in finishing heifers. J. Anim. Sci. 80(Suppl. 1):186. (Abstr.)

Milton, C. T., R. J. Cooper, and F. L. Prouty. 1999. Delayed implant strategies using Synonex Plus for finishing yearling steers. J. Anim. Sci. 77(Suppl. 1):232. (Abstr.)

Milton, T., T. Klopfenstein, D. J. Jordan, R. Cooper, and R. Stock. 2000. Effect of dry, wet, or rehydrated corn bran on performance of finishing yearling steers. Pages 61-62 in 2000 Nebraska Beef Report, MP 73-A. Univ. Nebraska, Lincoln.

Nelson, M., R. Gates, N. Voyles, T. Klopfenstein, R. Britton, and J. Ward. 1984. Methods of ammoniation of roughages. Pages 3740 in 1984 Nebraska Beef Report, MP 47. Univ. Nebraska, Lincoln.

Nelson, M., I. Rush, T. Klopfenstein, and R. Carr. 1982. Wintering steer calves. Pages 40-41 in 1982 Nebraska Beef Report, MP 43. Univ. Nebraska, Lincoln.
Nelson, M., I. Rush, E. Owen, C. Cajal, T. Klopfenstein, J. Wards, and R. Britton. 1983. Ammonia or alkali treatment and protein supplementation. Pages 27-31 in 1983 Nebraska Beef Report, MP 44. Univ. Nebraska, Lincoln.

NRC. 1996. Nutrient Requirements of Beef Cattle. 7th ed. National Academy Press, Washington, DC.

NRC. 2000. Nutrient Requirements of Beef Cattle: Update 2000. 7th rev. ed. Natl. Acad. Press, Washington, DC.

NRC. 2001. Nutrient Requirements of Dairy Cattle. 7th ed. National Academy Press, Washington, DC.

Pankaskie, D., and T. Mader. 1985. Alfalfa hay vs. alfalfa silage for growing calves. Pages 67-69 in 1985 Nebraska Beef Report, MP 48. Univ. Nebraska, Lincoln.

Pankaskie, D., T. Mader, R. Britton, and K. Rump. 1983. Preservatives (microbial) for alfalfa silage. Pages 32-33 in $1983 \mathrm{Ne}-$ braska Beef Report, MP 44. Univ. Nebraska, Lincoln.

Paterson, J., T. Klopfenstein, and L. Petersen. 1980a. Corn plant residue ammonia treatment. Pages 24-26 in 1980 Nebraska Beef Report, EC 80-218. Univ. Nebraska, Lincoln.

Paterson, J., T. Klopfenstein, and L. Petersen. 1980b. Hydroxide treated cobs, alfalfa. Pages 26-27 in 1980 Nebraska Beef Report, EC 80-218. Univ. Nebraska, Lincoln.

Patterson, T., T. Klopfenstein, T. Milton, and D. Brink. 2000. Evaluation of the 1996 beef cattle NRC model predictions of intake and gain for calves fed low or medium energy density diets. Pages 26-29 in 2000 Nebraska Beef Report, MP 73-A. Univ. Nebraska, Lincoln.

Rice, J. A., and P. A. Cochran. 1984. Independent evaluation of a bioenergetics model for largemouth bass. Ecology 65:732-739.

Richards, C., R. Stock, T. Klopfenstein, and D. Shain. 1995. Effect of wet corn gluten feed and supplemental protein on calf finishing performance. Pages 26-28 in 1995 Nebraska Beef Report, MP 62-A. Univ. Nebraska, Lincoln.

Roth, L., T. Klopfenstein, and W. Sahs. 1988. Corn stalkage for growing calves - A review. Pages 51-56 in 1988 Nebraska Beef Report, MP 53. Univ. Nebraska, Lincoln.

Roth, L. D., S. J. Anderson, and T. Klopfenstein. 1986. Bypass protein or alfalfa with ammoniated crop residues. Pages 48-51 in 1986 Nebraska Beef Report, MP 50. Univ. Nebraska, Lincoln.

Rush, I., B. Weichenthal, and B. Van Pelt. 1992. Levels of pressed sugarbeet pulp in growing diets. Pages 24-25 in 1992 Nebraska Beef Report, MP 58. Univ. Nebraska, Lincoln.

Rush, I., B. Weichenthal, and B. Van Pelt. 1998. Cull dry edible beans in growing calf rations. Pages 68-71 in 1998 Nebraska Beef Report, MP 69-A. Univ. Nebraska, Lincoln.

Rush, I. G., and B. Van Pelt. 1987. Whole and cracked corn...high roughage growing rations. Pages 56-57 in 1987 Nebraska Beef Report, MP 52. Univ. Nebraska, Lincoln.

Scott, T., T. Klopfenstein, D. Shain, and M. Klemesrud. 1997a. Wet corn gluten feed as a source of rumen degradable protein for finishing steers. Pages 70-72 in 1997 Nebraska Beef Report, MP 67-A. Univ. Nebraska, Lincoln.

Scott, T., T. Klopfenstein, R. Stock, and M. Klemesrud. 1997b. Evaluation of corn bran and corn steep liquor for finishing steers. Pages 72-74 in 1997 Nebraska Beef Report, MP 67-A. Univ. Nebraska, Lincoln.

Scott, T., T. Milton, T. Klopfenstein, and R. Stock. 2001. Corn processing method in finishing diets containing wet corn gluten feed. Pages 59-63 in 2001 Nebraska Beef Report, MP 76-A. Univ. Nebraska, Lincoln.

Scott, T., T. Milton, T. Mader, T. Klopfenstein, and R. Cooper. 1999. Effects of programmed gain on performance and carcass characteristics in calves. Pages 46-48 in 1999 Nebraska Beef Report, MP 71-A. Univ. Nebraska, Lincoln.

Shain, D., T. Klopfenstein, R. Stock, and M. Klemesrud. 1996. Implant and slaughter time for finishing cattle. Pages 72-73 in 1996 Nebraska Beef Report, MP 66-A. Univ. Nebraska, Lincoln.

Shain, D., T. Klopfenstein, R. Stock, and B. Vieselmeyer. 1995. Grazing systems utilizing forage combinations. Pages 18-20 in 1995 Nebraska Beef Report, MP 62-A. Univ. Nebraska, Lincoln. 
Shain, D., M. Sindt, R. Grant, T. Klopfenstein, and R. Stock. 1993. Soyhulls:lecithin:soapstock mixture for growing beef calves. Pages 34-35 in 1993 Nebraska Beef Report, MP 59-A. Univ. Nebraska, Lincoln.

Trotter, T., R. Olson, B. Brown, T. Klopfenstein, D. Brink, and R. Stock. 1981. Effects of Rumensin in high fiber growing rations. Pages 13-16 in 1981 Nebraska Beef Report, EC 81-218. Univ. Nebraska, Lincoln.
Vieselmeyer, B., T. Klopfenstein, R. Stock, and R. Huffman. 1994. Extensive beef production systems: Forage combinations managed as one unit. Pages 20-22 in 1994 Nebraska Beef Report, MP 61-A. Univ. Nebraska, Lincoln.

Vieselmeyer, B. A., R. J. Rasby, B. L. Gwartney, C. R. Calkins, R. A. Stock, and J. A. Gosey. 1996. Use of expected progeny differences for marbling in beef: I. Production traits. J. Anim. Sci. 74:1009-1013. 